to the perborate chemical bleach include yellowing, said to be due to incomplete rinsing, and loss of colour, both generally and in spots. The latter were attributed to incomplete solution of the perborate in the hot water before the articles to be washed were put in. Two speakers said that they had seen advertisements for detergents on television in which this incorrect and dangerous procedure was shown. It was generally agreed that loss of strength is not a problem and that when it does occur, faulty rinsing is the cause. Bleaching on the line, especially during drying in sunlight, was also attributed to this cause. Serious disquiet was expressed at a report of the addition of bleaches containing chlorine to domestic detergents in the United States, and of their possible use in Britain.

A number of speakers made it clear that they considered that some detergent compositions, likely to cause damage to some textile goods of high quality, are being sold to housewives without adequate and sufficiently clear instructions. It is claimed by the manufacturers of these detergents that their inquiry and education services find none of the faults described. On the other hand, a manufacturer of baby clothes who guarantees to replace faulty goods has reported numerous complaints of change of colour, and said that a recommendation to use a selected detergent free from the objectionable additions has led to a large decrease in the number of complaints. He suggested clear classification of all detergents into two groups, one for whites and one for coloured goods. This and similar labelling proposals were received with applause by the meeting. It was stated that the dyestuff makers were unable to produce an optical bleach fast to detergents.

Dr. A. S. C. Lawrence, summing up, said that three main points had emerged from the meeting. First, that the light-fast dyes, which the dye maker can produce, require dyeing processes to make them fast to detergent compositions as now generally sold and this involves extra cost. Secondly, that the textile manufacturer receives the complaints, for the obvious reason that a woman who has purchased a relatively expensive article will complain to the shop where she bought it rather than write to the manufacturer from whom she has obtained a few pennyworth of detergent. Thirdly, that communication of highly technical matters to and from a technologically ignorant public is impossible, and the claims of success of inquiry and education services of the detergent manufacturers must be regarded with suspicion. New textile goods heavily loaded with optical bleach are already being sold, so that a ban on fluorescent brighteners in detergents would not be enough. It seems that some co-operative standard of labelling by makers of detergents, to distinguish in a simple and unequivocal manner for the ordinary housewife the basic types of composition, is the only satisfactory solution and one much overdue. Alternatively, makers of textiles will have to label their goods, specifying a safe detergent, until the makers of the present potentially harmful compositions, so widely sold, are driven to a more critical consideration of their duty to the public. A. S. C. LAwRENCE

\title{
FORESTRY IN THE UNITED KINGDOM
}

W HILE the Society of Foresters of Great Britain, having been formed in 1925 , is the youngest of the British societies concerned with forestry, its membership is the most representative of the profession as, although it has an ordinary membership open to all who are interested, it caters primarily for the university graduate and others with equivalent qualifications. Its journal, Forestry, is published twice yearly. During the past year, it has published about a dozen original articles ranging over a very wide field, tending to be ecological rather than technical, though some of them link the two aspects; for example, a study of the effect of rate of growth on the density of timber.

The opening article in the 1958 volume is a thoughtful study by G. B. Ryle (at the time, the Forestry Commission director for Wales) on the social problems and possible developments in upland grazing areas where forestry is the obvious alternative use to sheep farming. A strong case is made for integration of farming and forestry, both uses being taken equally into account; action should be co-ordinated by combined councils and the mistakes of the past should be avoided. There have been faults on both sides, the agriculturist seeing the problem as one of maintaining the farm with the help of subsidies, etc., even when it is uneconomical, or less economical than alternative uses, while the forester has tended to overlook the fact that both winter and summer feed must be available to a sheep farm. Ryle also adduces fairly conclusive evidence that forestry gives more on-the-spot employment than sheep farming- probably twice as much-and stresses the need for improved housing as extensions of existing communities rather than new isolated centres.

A study of the mineral content of standing pine crops on the Culbin Sands by T. W. Wright and G. M. Will shows that a maturing crop with about 50 tons of dry organic substance contains about $170 \mathrm{lb}$. nitrate, $20 \mathrm{lb}$. phosphate, $100 \mathrm{lb}$. potassium, $160 \mathrm{lb}$. calcium and $32 \mathrm{lb}$. magnesium, of which about one-third to one-quarter is in the leaves and so returned to the ground annually; the wood, which alone is ultimately removed (provided the bark is peeled on the spot), contains less than one-fifth of the total. These figures, despite their smallness, are of considerable significance in relation to the very low mineral content of the blown sand.

Two papers deal with different aspects of a field that is attracting increasing attention, namely, the relation between the physical conditions, both natural and due to manipulation, under which trees are grown, and the properties of the timber they produce. Studies of site factors influencing growth are discussed in another two papers dealing, respectively, with wind effects and the measurement of light intensity. Taxonomic studies are represented by a paper on the elms of south Cambridgeshire and one on the named variants of the Scots pine. In view of the importance of the latter tree in afforestation and its wide distribution and range of forms, this analysis of 144 terms already published is a most useful contribution : it describes no less than twentysix geographical varieties and twenty-five habit 
forms, together with many named variations in bark, foliage, cones, timber and seed.

The Royal Scottish Forestry Society was founded as the Royal Scottish Arboricultural Society in 1855 and its published transactions have developed into the current quarterly Scottish Forestry. While this Society draws its membership from a wider field than the Society of Foresters of Great Britain, and has a much bigger proportion of the non-professional element, its journal regularly includes original articles of considerable interest and value. Among those appearing during the year, mention may be made of a paper on the practical issue of using a knowledge of the life-history of the fungus (Keithia) which is liable to affect seriously the growth of Thuja seedlings, to raise healthy nursery stock of this tree; isolated nurseries used once only or in rotation, with due precautions to avoid sources of infection, are the solution. There is an interesting paper on the variation of susceptibility of European larch of different seed origins to frost, and another on 'group strike' by lightning, a case being reported of one hundred trees dying with only two showing actual scars, and a comparable case in a nursery. The morphological field is represented by a paper on bark variation in birch and its relation to figured wood.

The present Royal Forestry Society of England and Wales was founded in 1882 as the English Arboricultural Society, on similar lines to its Scottish counterpart. Its transactions appeared from 1884, becoming the Quarterly Journal of Forestry in 1907. As might be expected, a very similar range of original papers is being published, including in 1958 three on the properties of coniferous timbers as affected by treatment during growth, one on the effect of liming ploughed or unploughed upland moors, and one on the 'mechanized forest'.

Mention should not be omitted of the Empire Forestry Review, published quarterly by the Empire Forestry Association, which includes a proportion of original articles on British forestry among its much wider coverage ; these are chosen primarily for their general interest though, of course, forestry issues are very similar all over the world. The chief items of this type in 1958 are on desirable road density in plantations and intensive methods of raising coniferous seedlings. In addition, there are the 'Men of the Trees' publishing Trees two or three times a year.
H. G. Champion

\title{
FOOD INVESTIGATIONS
}

\begin{abstract}
HE recently published report of the Food Investigation Board* for 1957 also covers the work of the Torry Research Station and the Humber Laboratory concerning the improved handling and processing of fish; the Low Temperature Research Station on meat, eggs and various plant foods; and the Ditton Laboratory and the Covent Garden laboratory concerned mainly with conditions of storage for fruit and vegetables.

A report of this nature provides an excellent illustration of the complexity of the problems associated with the maintenance of an all-the-year-round supply of food in an industrialized, urbanized community. In the main, the work is concerned with preserving food and this requires a study of differences in the initial state of the food, of the conditions of handling to which it may be subjected, and of

* Department of Scientific and Industrial Research. Food Investigation 1957 : The Report of the Food Investigation Board with the Reports of the Superintendents of the Torry Researeh Station, the Low Temperature Research Station, and the Ditton Laboratory. Pp. vi +81 . (London : H.M. Stationery Office, 1958.) $5 s$. net.
\end{abstract}

methods of detecting early stages of deterioration, quite as much as a study of all aspects of the different methods of preservation, which include such varied means as the use of antibiotic ice, electronic radiation, electrostatic smoking, vacuum freeze-drying, gas storage, etc.

The Board stresses "the vital importance of the closest possible co-operation with the appropriate user industry from the outset of a research through all its stages to its final implementation". Several of the investigations concerning fish were made at the request of the White Fish Authority, the Herring Industry Board, and the National Federation of Fishmongers, and a committee of the National Farmers' Union was consulted when the research programme of the Ditton Laboratory was being planned. This is welcome collaboration and should not only ensure direction of effort towards the problems most urgently in need of solution but also speedy application of any solutions which might be found.

M. W. Grant

\section{REMANENT MAGNETISM OF THE ALLARD LAKE ILMENITES}

\author{
BY CHARLES M. CARMICHAEL \\ Department of Geophysics, University College, University of Western Ontario
}

$\mathrm{T}^{2}$ WE Allard Lake region of Quebec contains numerous outcrops of massive ilmenite enclosed in Grenville-type anorthosite of pre-Cambrian age. Hammond ${ }^{1}$ has deseribed the region, particularly the Lac Tio deposit, which is the largest of its type in the world.

Although the ore is usually referred to as ilmenite, it should be called hemoilmenite, since it consists of about 70 per cent ilmenite $\left(\mathrm{FeTiO}_{3}\right)$ and 25 per cent hematite $\left(\mathrm{Fe}_{2} \mathrm{O}_{3}\right)$, with the remainder being largely composed of feldspar, pyroxene and pyrite. The massive ore consists of relatively large crystals averaging about 3-5 $\mathrm{mm}$. in diameter. The hemoilmenite solidified originally in homogeneous crystals, and then upon cooling separated by exsolution into an ilmenite-rich phase and a hematite-rich phase. The hematite-rich phase has exsolved in the form of thin discontinuous lamellæ with their long and intermediate axes in the basal plane of the rhombohedral host-crystal. Thus the lamellæ have the general 